\title{
Study of Reproductive Behavior of Adult Male (Crocodile) in Kotmi Sonar of Janjgir Champa (C.G.)
}

\author{
Kavita Gabel $^{1}$, Manoj Gabhel ${ }^{2}$ \\ ${ }^{1,2}$ M. Phil. Scholar, Dr. C.V. Raman University Bilaspur (C.G), India
}

\begin{abstract}
Crocodile has been categorized as a vulnerable species in the Red List of IUCN and is placed under schedule 1 of the Wild Life Protection Act, 1972. To protect Crocodiles a Crocodile Conservation Park has been established by The Govt. of Chhattisgarh in Munda pond of Kotmi Sonar, District Janjgir - Champa, (C. G.) India. The physicochemical conditions of Munda pond provide an optimal conditions for, growth and vital activities for this species, Crocodylus palustris. The population of Crocodylus palu stris is gradually increasing up to 378. The establishment of incubation centre, artificial hatchery and other technical facilities helps in the increasing population of Crocodylus palustris. The potentialities of Crocodile Park showed explored from point of view of knowledge, research activities and ecotourism as well.
\end{abstract}

Keywords: Conservation, Eco tourism, vulnerable species

\section{Introduction}

The Marsh Crocodile, Mugger or Crocodylus palustris is a common and widespread crocodilian species in India [Vyas, 2012]. Crocodylus palustris is ecto and heterothermic, seasonal breeder, gonochoric, diocious, hole-nesting and oviparous species [Jacobson, 1999; Da Silva and Lenin, 2010]. The population of Crocodylus palustris is reportedly declining [Whitaker and Andrews, 2003; Oza, 1975]. The population is reportedly declining due to illegal hunting for skin and indigenous medical purpose, habitat destruction. Lack of appropriate 'rescue and release' protocols and man made causes are another causes for shrinking population of Crocodylus palustris [Vyas, 2012; Da Silva and Lenin. 2010; Whitaker and Whitaker, 1984; Joshi et al., 2011; Vyas and Vyas, 2002; Vyas, 2010]. Their global population is tentatively estimated as 5400 to 7100 non-hatching [Da Silva and Lenin, 2010]. To protect and conserve this endangered species, it has been categorised as a vulnerable species in the Red List of IUCN and Red List of threatened Reptilian species. It is placed under schedule 1 of Wild Life Protection Act, 1972 [Joshi et al., 2011; Choudhury and Chowdhury, 1986; Bharos and Kanoje, 2007]. To provide a higher degree of protection to Crocodylus palustris, a Crocodile Conservation Park is established in Munda pond at Kotmi Sonar of Janjgir-Champa District of Chhattisgarh, India [Fig. no. 1]. Crocodiles were observed here during basking from 08.00 A.M. to 05.00 P.M. The presence of 16 - 17 transverse rows of dorsal shield, usually two median rows are considerably broader [Fig. no. 2], 4 - 6 longitudinal series of scutes, broadest snout with 19 upper teeth and an externally visible cone shaped 4th tooth on each side are the characteristics of Crocodylus palustris [Da Silva and Lenin, 2010] [Fig. no. 2].

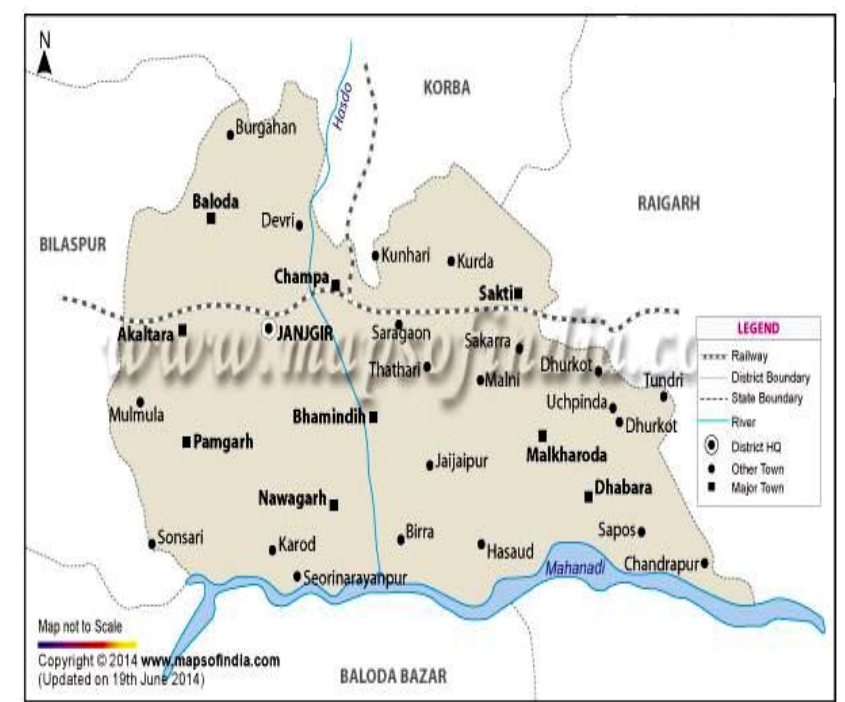

Figure 1: Showing Study area (Crocodylus palustris) Kotmi Sonar,Dist.Janjgir Champa ,Chhatisgarh

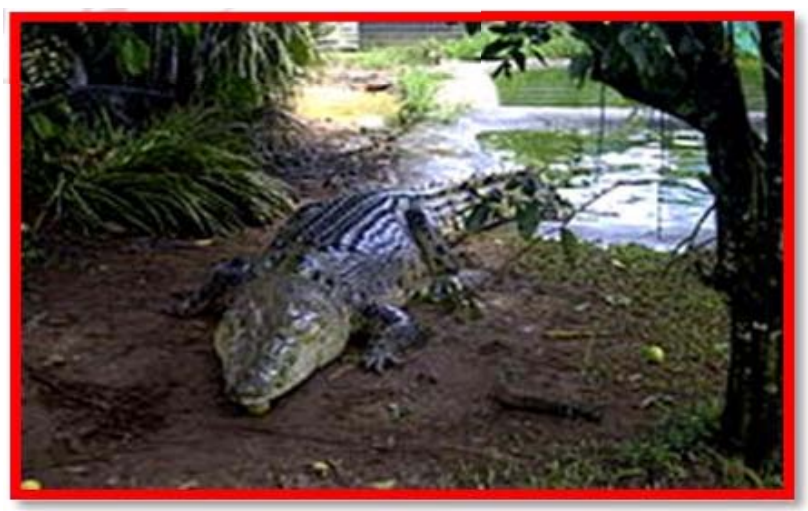

Figure 2

The present study was conducted in Kotmi Sonar. The Kotmi Sonar is an ancient village of District Janjgir - champa (Chhattisgarh) India. It lies at 220, 01'; 44.8" north latitude and 820, 21', 13.1" east longitude [Bharos and Kanoje, 2007]. It is situated in Mumbai Howrah railway line between 


\section{International Journal of Science and Research (IJSR) \\ ISSN (Online): 2319-7064}

Index Copernicus Value (2015): 78.96 Impact Factor (2015): 6.391

Bilaspur and Champa junctions of Chhattisgarh, India [Fig. no. 1]. The Munda pond is spread on 85 acre area. The terrain of Kotmi Sonar is almost plain with gentle slope. The Kotmi Sonar is situated in 620 meters above M.S.L. The underlying rocks are granite, schist and limestone [Bharos and Kanoje, 2007]. In the present study, four study sites [at four corners] were pointed out.

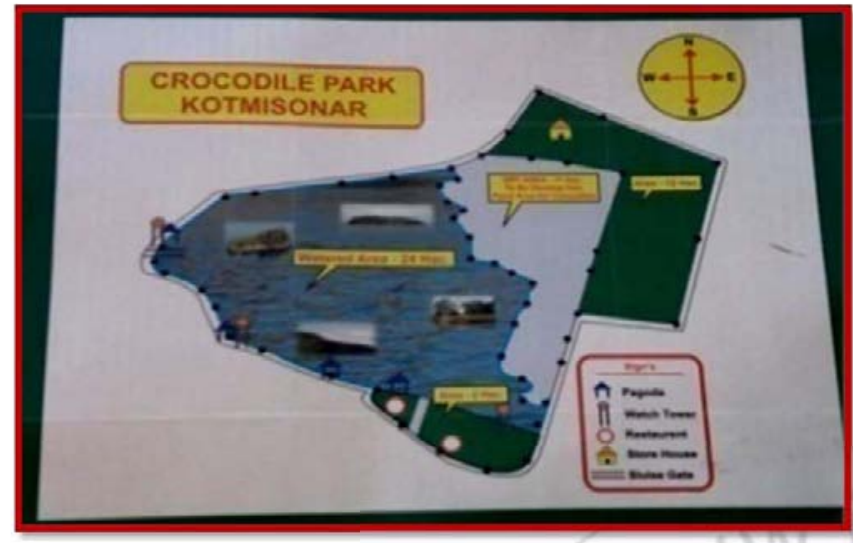

Figure 3: Area of Kotmi Sonar (Mundapond)

Our qualitative analysis focuses primarily on the behaviours of adults during three phases of reproduction :-

1) Defense of Territory and courtship,

2) Nesting and Incubation,

3) Hatching and Post hatching.

\section{Material and Method}

The visual ground survey method was used to identify the morphological characteristics and study of behavioral responses. 'Direct Counting Method' and 'Capture and Release Technique' were used to estimate the population of Crocodiles. The indirect evidences such as foot prints, sign of body impressions were also studied. Useful Tools is Technical, camera, interview, visual observation.

\section{Observation}

Population estimated by "Direct counting method" and "Capture and release technique". Visual observation, interaction with local people and Departmental field staff were made for the behavioural study of Crocodylus palustris.

Table 1: Population Survey of Crocodylus Palustris (Male+Female+Juveniles) in Kotmi Sonar in JanjgirChampa_(C.G.)

\begin{tabular}{|c|c|c|c|c|}
\hline Sample Site & Male & Female & Juveniles & Total \\
\hline A & 06 & 09 & 50 & 65 \\
\hline B & 06 & 07 & 35 & 48 \\
\hline C & 08 & 11 & 30 & 49 \\
\hline D & 05 & 08 & 45 & 58 \\
\hline Total & 25 & 35 & 160 & 220 \\
\hline
\end{tabular}

Table 2: Sound, Signaling, Courtship, Mating of Crocodylus palustris

\begin{tabular}{|c|c|c|c|c|}
\hline \multirow{2}{*}{ Sno } & \multicolumn{4}{|c|}{ Reproductive Behaviour } \\
\hline & Activities & Month & Weeks & Observation \\
\hline \multirow[t]{4}{*}{1} & \multirow{4}{*}{$\begin{array}{c}\text { Pre- } \\
\text { mating }\end{array}$} & \multirow{4}{*}{$\begin{array}{c}\text { January } \\
2016\end{array}$} & $1^{\text {st }}$ & Normal activities \\
\hline & & & $2^{\text {nd }}$ & Normal activities \\
\hline & & & $3^{\text {rd }}$ & Normal activities \\
\hline & & & $4^{\text {th }}$ & Some crocodiles between fighting \\
\hline \multirow[t]{12}{*}{2} & \multirow[t]{12}{*}{ Mating } & \multirow[t]{4}{*}{$\begin{array}{c}\text { February } \\
2016\end{array}$} & $1^{\text {st }}$ & $\begin{array}{l}\text { Normal activities Showing by } \\
\text { Crocodiles }\end{array}$ \\
\hline & & & $2^{\text {nd }}$ & Pair were showing copulation \\
\hline & & & $3^{\text {rd }}$ & Normal activities \\
\hline & & & $4^{\text {th }}$ & Normal activities \\
\hline & & \multirow{4}{*}{$\begin{array}{l}\text { March } \\
2016\end{array}$} & $1^{\text {st }}$ & Pair were showing copulation \\
\hline & & & $2^{\text {nd }}$ & Normal activities \\
\hline & & & $3^{\text {rd }}$ & Normal activities \\
\hline & & & $4^{\text {th }}$ & Normal activities \\
\hline & & \multirow{4}{*}{$\begin{array}{l}\text { April } \\
2016\end{array}$} & $1^{\text {st }}$ & Eggs were laying by female \\
\hline & & & $2^{\text {nd }}$ & Normal activities \\
\hline & & & $3^{\text {rd }}$ & Eggs were laying by female \\
\hline & & & $4^{\text {th }}$ & Normal activities \\
\hline \multirow[t]{8}{*}{3} & \multirow{8}{*}{$\begin{array}{c}\text { Post- } \\
\text { mating }\end{array}$} & \multirow{4}{*}{$\begin{array}{l}\text { July } \\
2016\end{array}$} & $1^{\text {st }}$ & Normal activities \\
\hline & & & $2^{\text {nd }}$ & $\begin{array}{l}\text { 1Female showing hatching } \\
\text { activities }\end{array}$ \\
\hline & & & $3^{\text {rd }}$ & Normal activities \\
\hline & & & $4^{\text {th }}$ & Some juveniles into water \\
\hline & & \multirow{4}{*}{$\begin{array}{l}\text { August } \\
2016\end{array}$} & $1^{\text {st }}$ & Normal activities. \\
\hline & & & $2^{\text {nd }}$ & $\begin{array}{c}\text { Juveniles were come out from } \\
\text { eggs. }\end{array}$ \\
\hline & & & $3^{\text {rd }}$ & Normal activities. \\
\hline & & & $4^{\text {th }}$ & Some juveniles into water. \\
\hline
\end{tabular}

Table 3: Study Sit (A, B, C, D) area of Male Crocodylus Palustris are mean \pm SE 6 of animals

\begin{tabular}{|c|c|c|c|c|}
\hline S. No. & \begin{tabular}{|c} 
Male Length \\
of Study Site \\
A \\
\end{tabular} & \begin{tabular}{|c} 
Male Length \\
of Study Site \\
B \\
\end{tabular} & \begin{tabular}{|c}
$\begin{array}{c}\text { Male Length } \\
\text { of Study Site } \\
\mathrm{C}\end{array}$ \\
\end{tabular} & \begin{tabular}{|c}
$\begin{array}{c}\text { Male Length } \\
\text { of Study Site } \\
\text { D }\end{array}$ \\
\end{tabular} \\
\hline 1 & 3.14 & 4.56 & 8.22 & 5.89 \\
\hline 2 & 5.65 & 4.41 & 4.64 & 5.22 \\
\hline 3 & 5.00 & 3.00 & 3.89 & 5.10 \\
\hline 4 & 8.00 & 3.85 & 3.40 & 6.45 \\
\hline 5 & 10.00 & 3.49 & 6.00 & 6.85 \\
\hline 6 & 9.00 & 5.56 & 9.64 & 7.00 \\
\hline 7 & 3.65 & - & - & - \\
\hline$\frac{2 x}{N}$ & $/ 7$ & $6 / 3$ & $=35.79 / 6$ & $=36.51 / 6$ \\
\hline$\overline{\bar{X}}$ & $=6.35$ & $=4.16$ & $=5.96$ & $=6.08$ \\
\hline$\sigma$ & \pm 2.47 & \pm 0.84 & \pm 2.28 & \pm 0.74 \\
\hline SE & \pm 0.93 & \pm 0.34 & \pm 0.93 & \pm 0.30 \\
\hline
\end{tabular}

Table 4: Comparative study of A, B, C,D area Male Crocodylus Palustris, Values are mean $\pm \mathrm{SE}$ the figure in parentheses indicate number of animal.

\begin{tabular}{|c|c|}
\hline Study Site & Female Length (Meter) \\
\hline A & $\begin{array}{c}6.35 \pm 0.93 \\
(7)\end{array}$ \\
\hline B & $\begin{array}{c}4.16 \pm 0.34^{*} \\
(6)\end{array}$ \\
\hline C & $\begin{array}{c}5.96 \pm 0.93 \\
(6)\end{array}$ \\
\hline D & $\begin{array}{c}6.08 \pm 0.30 \\
(6)\end{array}$ \\
\hline
\end{tabular}




\section{International Journal of Science and Research (IJSR) \\ ISSN (Online): 2319-7064}

Index Copernicus Value (2015): 78.96 Impact Factor (2015): 6.391

\section{Results}

Reproductive Behavior - A adult female Reproctive behavior is well in Mundapond. So Crocodylus Palustris (Male+Female+Juveniles) is gradually increasing The Environmental \& Physico chemical-condition is well of Munda pond for reproductive so this area is very good for Species of Crocodylus Palustris.

The result in this chapter is supported by the statistical analysis presented in the form of table given under different sections.

Population survey of Crocodylus Palustis in Kotmi Sonar of Janjgir-Champa (C.G.) (January 2016 - August 2016) show total no of female + male + juveniles.

I observe Crocodylus Palustris in Munda pond in this time species show different activities in different month. . My weekly observation show in (January 2016 - August 2016) female Crocodylus Palustris so different activities in every week.

Study site A,B,C,D area in Munda pond female Crocodylus Palustris, Nestling, Incubation, hatching and post hatching, Values are mean \pm SE of 7,6,6,6 animals in Male Crocodylus Palustris, nestling, incubation, hatching and post hatching comparative Account of A,B,C,D of site area .The physicochemical factors effect the distribution and population of crocodile [Sahato, 2004]. It was reported that crocodile population is threatened in low water quality [Joshi et al. 2011]. The variation and access limits of physicochemical parameters were the causes of harmful effects on the population of crocodiles [Chang et al., 2013]. Rubbery of snout and hunch back conditions were occurring in the high level of calcium [Singh et al., 2001]. Low water level without replacement is another cause of bacterial infection in hatchling of Crocodiles [Misra et al., 1993]. The poor water quality and extreme humidity in mansoon causes some myotic infection and death of hatchlings Crocodiles [Lal, 1982; Maskey, 1989].

\section{Conclusion}

C.P. Crocodylus palustris is a Red listed species so conservation is required our nearest place village Kotmi sonar Distt. Janjgir-Champa(C.G.) a big conservation area for crocodile species (Crocpdylus Palustris). This place soil, water and environmental condition is very perfect for reproduction by Crocodylus palustris. Their number increase in this place juveniles and adult growth is well and reproduction condition is well. Female is healthy and strange and their breeding states is very well.

Crocodylus palustris number and population very important for biodiversity and nature and other crocodilians. So save crocodiles you know crocodiles threaten species, so their conservation is very important. Crocodile very important, animal for every think Ex-food biodiversity, medical purpus, ecosystem, food chain, food wed, for fashion, for goods and this is very different another species.

\section{References}

[1] Apha, $14^{\text {th }}$ ed. Standard methods for the examination of water and waste water, Washington, D.C. (1998)journal style)

[2] Bharos, A. M. K. and Kanoje, R. S., Wetlands of Kotmi Sonar, an abode of marsh Crocodile, Proceedings of Taal, The 12th world lake conference, 1796-1997, (2007).

[3] Chang, M. S., Gachal, G. S., Qadri, A. H., Sheikh, M. Y., Physico-chemical assessment and its impacts on Marsh Crocodiles of Karachi Zoological Garden, International Journal of Advanced Research, 1, (3), 102-107, (2013).

[4] Choudhury, B. C., and Chowdhury, Lessons from crocodile reintroduction projects in India, Indian forester 112, 881-890, (1986).

[5] Da silva, A. and Lenin, J., Mugger Crocodile Crocodylus palustris. In: S. C. Manolis, C. Stevenson, (Eds.) Crocodile: Status survey and conservation action plan, Third edition. Crocodile specialist group : Darwin, 94-98, (2010).

[6] Jacobson, C., Reintroduction of the Mugger Crocodile, Crocodylus palustris, in India, Restoration and Reclamation Review, Student on-line Journal, 4, (3), 17, (1999).

[7] Joshi, R., Singh, R. and Negi, M. S., First record of mugger crocodile Crocodylus palustris (Lesson, 1831) from the Rajaji National Park, North India, International Journal of Biodiversity and Conservation vol. 3, (9), 444-450, (2011).

[8] Lal, S., Diseases in Gharial Juveniles, Journal of Wildlife preservation Society of India, 23 (3), 38-40. (1982)

[9] Maskey, T. M., Movement and survival of captive reared Gharials (Gavialis gangeticus) in Narayani River, Nepal, Ph. D. Dissertation, Graduate school, University of Florida, United State of America, (1989).

[10] Misra, P., Kumar, R. D., Patanayak, G. M., Rahman, R. P., Singha, A., Bacterial isolates from apparently healthy and diseased crocodiles (Gavialis gangeticus), Indian Veterinary Journal, 70, 375-376, (1993).

[11] Oza, G. M., Conservation of the crocodile in the Sayaji Sarovar Lake, Baroda, India. Biology Conservation, 7, 235-236, (1975).

[12] Sahato, G. A., Lashari, K. H., Sahato, S. B., Hamdard Medicusvol, XL VII No (4), 100, (2004).

[13] Singh, L. A. K., Observation on the movement of two captive reared Mugger Crocodiles, Crocodylus palustris when returned to the wild, Journal of the Bombay Natural history society, 80, 86- 90, 1983.

[14] Singh, L. A. K., Srivastav, S. S., Mohanty A. P. and Raut, S. D., Prevention of rubbery snout and X-ray revelations on hunchback condition of Mugger crocodile (Crocodylus palustris), 220's print Journal 16 , (4), 465-466, (2001).

[15] Vyas, R., Current status of Marsh Crocodiles Crocodylus palutris (Reptilia: Crocodylidae) in Vishwamitri River , Vadodara City, Gujrat, India, Journal of threatened taxa, 4, (14), 3333-3341, (2012). 
[16] Vyas, R. and Vyas, R., Mugger survey in the Vishwamitri River of Gujrat, India. CSG Newsletter, 21(3), 9-110, (2002).

[17] Vyas, R, Mugger (Crocodylus palustris) Population in and around Vadodara City, Gujrat State, India. Russian Journal of Herpetology, 17, (1), 43-50, (2010).

[18] Whitaker, R. and Whitaker, Z., Reproductive biology of the Mugger, J. Bombay Natural history society 81, (2), 297-316, (1984). 